УДК [UDC] 621.313.333.2+ 06

DOI 10.17816/transsyst201842167-179

(C) V. Solomin ${ }^{1}$, A. Solomin ${ }^{1}$, V. Koledov ${ }^{2}$, N. Trubitsina ${ }^{1}$

${ }^{1}$ Rostov State Transport University

(Rostov-on-Don, Russia)

${ }^{2}$ V. A. Kotelnikov Institute of Radio Engineering and Electronics

of the Russian Academy of Science

(Moscow, Russia)

\title{
MULTIFUNCTIONAL LINEAR INDUCTION MOTOR WITH LONGITUDINAL-TRANSVERCE MAGNETIC FLUX FOR MAGNETIC-LEVITATIONAL TRANSPORT
}

Background: Traction linear induction motors (LIM) at the current stage of human society development are the most promising for high-speed magnetic-levitation transport (MLT) and are already used in a number of commercial projects. Linear induction motors can be executed with longitudinal, transverse and longitudinal-transverse magnetic flux and have a large number of design options.

Aim: In addition to traction efforts, LIM develops the forces of magnetic-levitation and lateral stabilization (self-stabilization). The efforts of magnetic-levitation of linear induction motors with longitudinal and transverse magnetic flux are very significant in the zone of large slides (at low speeds) and decrease with increasing speed of the magneticlevitation transport. To a lesser extent, the decrease in slip (at high speeds) affects the magnetic-levitation forces developed by a number of design variants of linear induction motors with a longitudinal-transverse magnetic flux, in which magnetic fields traveling in a transverse direction towards each other are additionally used. This is explained by the fact that at high and low velocities MLT, the LIM slip will be equal to unity relatively oppositely running in the transverse direction of the magnetic fields and the magnetic suspension forces will be maximum.

Methods: Running towards each other in the transverse direction of the MLT movement, magnetic fields cross the electrically conductive secondary element (playing the role of the track structure of the high-speed transport system) and induce electromotive forces in it, under the influence of which currents will flow.

Results: As a result, cross counter-directional mechanical forces are created which, in the symmetrical arrangement of the MLT crew relative to the track structure, are mutually balanced and do not have any effect on the motion of the magnetic-levitation transport. At lateral (transverse) displacement of the high-speed transport on the magnetic suspension relative to the track structure, the equilibrium of the transverse mechanical forces is disrupted and, under the effect of the effort difference, the MLT crew will be automatically returned to the original symmetrical position.

Conclusion: The distribution of magnetomotive forces (MMF) of a linear induction motor with a longitudinal-transverse magnetic flux, whose magnetic system is formed by the combination of longitudinally and transverse laminated cores, on the teeth of which the coils of a concentrated three-phase winding are located, is considered. The relations are represented

The article was written with the support of RFBR_RDF grant № 17-20-04236 «Magnetic cooling of perspective transport and energy systems». 
in the form of a double Fourier series for calculating the resultant MMF value in the air gap of a linear induction motor with a longitudinal-transverse magnetic flux.

Keywords: Linear induction motor, Longitudinal-transverse magnetic flux, Magnetic levitation, Lateral stabilization, Magnetomotive force.

\author{
(C) В. А. Соломин ${ }^{1}$, А. В. Соломин ${ }^{1}$ В. В. Коледов ${ }^{2}$ Н. А. Трубицина ${ }^{1}$ \\ ${ }^{1}$ Ростовский государственный университет путей сообщения \\ (Ростов-на-Дону, Россия) \\ ${ }^{2}$ Институт радиотехники и электроники им. В.А. Котельникова РАН \\ (Москва, Россия)
}

\title{
МНОГОФУНКЦИОНАЛЬНЫЙ ЛИНЕЙНЫЙ АСИНХРОННЫЙ ДВИГАТЕЛЬ С ПРОДОЛЬНО- ПОПЕРЕЧНЫМ МАГНИТНЫМ ПОТОКОМ ДЛЯ МАГНИТНОЛЕВИТАЦИОННОГО ТРАНСПОРТА
}

\begin{abstract}
Обоснование: Тяговые линейные асинхронные двигатели (ЛАД) на современном этапе развития человеческого общества являются наиболее перспективными для высокоскоростного магнитолевитационного транспорта (МЛТ) и уже используются в ряде коммерческих проектов. Линейные асинхронные двигатели могут выполняться с продольным, поперечным и продольно-поперечным магнитным потоком и иметь большое количество вариантов конструкций.
\end{abstract}

Цель: Помимо тяговых усилий ЛАД развивают усилия магнитной левитации и боковой стабилизации (самостабилизации). Усилия магнитной левитации линейных асинхронных двигателей с продольным и поперечным магнитным потоком весьма значительны в зоне больших скольжений (при низких скоростях движения) и уменьшаются с ростом скорости движения магнитолевитационного транспорта. В меньшей мере уменьшение скольжения (при высоких скоростях движения) влияет на усилия магнитной левитации, развиваемые рядом конструктивных вариантов линейных асинхронных двигателей с продольно-поперечным магнитным потоком, в которых дополнительно использованы бегущие в поперечном движению направлении навстречу друг другу магнитные поля. Это объясняется тем, что и при высоких и при низких скоростях движения МЛТ скольжения ЛАД относительно встречно бегущих в поперечном направлении магнитных полей будут равны единице и усилия магнитного подвеса будут максимальными.

Методы: Бегущие навстречу друг другу в поперечном направлении движения МЛТ магнитные поля пересекают электропроводящий вторичный элемент (играющий роль путевой структуры высокоскоростной транспортной системы) и индуктируют в нем электродвижущие силы, под действием которых потекут токи.

Результаты: В результате создаются поперечные встречно направленные механические усилия, которые при симметричном расположении экипажа МЛТ относительно путевой структуры взаимно уравновешиваются и не оказывают никакого влияния на движение магнитолевитационного транспорта. При боковом (поперечном) смещении высокоскоростного транспорта на магнитном подвесе относительно путевой 
структуры равновесие поперечных механических усилий нарушится и под действием разности усилий экипаж МЛТ будет автоматически возвращен в исходное симметричное положение.

Выводы: Рассмотрено распределение магнитодвижущих сил (МДС) линейного асинхронного двигателя с продольно-поперечным магнитным потоком, магнитная система которого образована сочетанием продольно и поперечно шихтованных сердечников, на зубцах которых расположены катушки сосредоточенной трехфазной обмотки. Представлены соотношения в виде двойного ряда Фурье для расчета результирующего значения МДС в воздушном зазоре линейного асинхронного двигателя с продольно-поперечным магнитным потоком.

Ключевые слова: линейный асинхронный двигатель, продольно-поперечный магнитный поток, магнитная левитация, боковая стабилизация, магнитодвижущая сила.

\section{INTRODUCTION}

Magnetic levitation systems of high-speed transport, including vacuum ones, can occupy a worthy place in the world transport communications in the foreseeable future. Studies in the field of MLT and new technologies, using the phenomenon of magnetic levitation, in Russia have intensified in recent decades. The work on the creation and study of MLT and the use of magnetic suspension in industrial installations is carried out by Russian enterprises and organizations in Russia. The most significant results in this area of research have been achieved in St. Petersburg [1-7], where various systems of magnetic suspension are being developed and studied, scientific conferences and seminars are being held where the aspects of the functioning of high-speed magnetic-levitation transport are discussed, and an engineering cluster «Russian Maglev» was created. In addition to magnetic levitation systems, it is necessary to carry out work in the field of traction drive to create new types of MLT, where the main element is a linear motor. Linear motors for high-speed MLT can be induction and synchronous. At the present stage of development of high-speed transport systems, in our opinion, the most promising are linear traction induction motors. Traction LIM has been successfully operated in China for many years on a magnetic-levitation train connecting Shanghai with the airport. Linear induction motors can have various designs of magnetic cores (solid, discrete) and windings (distributed, concentrated, three- and two-phase). In our opinion, LIM with longitudinal-transverse magnetic flux is very promising for magneticlevitation and vacuum transport, since these linear motors not only create traction and levitation forces, but also are capable of providing lateral stabilization of high-speed crew. 


\section{LINEAR INDUCTION MOTORS WITH A LONGITUDINAL- TRANSVERSE MAGNETIC FLUX}

In linear induction motors with a longitudinal-transverse magnetic flux, magnetic systems allow magnetic lines of force to be closed in both longitudinal and transverse directions, which expands their functional capabilities. In a highspeed MLT, linear induction motors with a longitudinal-transverse magnetic flux, in which the same magnetic fields «run» towards each other in each crosssection of the LIM, can realize not only traction and levitation forces, but lateral stabilization, which increases the safety of traffic. Note, that lateral stabilization efforts when the crew is shifted are created automatically without any sensors and additional devices, due to changes in the magnetic fields counter-running in the transverse direction. Linear induction motors with a longitudinal-transverse magnetic flux have different design versions, but for high-speed magneticlevitation transport, in our opinion, LIM is better suited, the multi-phase windings of which have connection circuits forming the same order of phases in the direction of vehicle movement, and in the transverse direction - to the middle of the series one, and after the middle - the opposite order of the phases [8-15]. The operating principle of the LIM data with a longitudinal-transverse magnetic field will be the same. When a multiphase winding of the LIM inductor is connected to a voltage source running magnetic fields are excited that cross the electrically conductive track structure, which plays the role of an anchor, and induce electromotive forces in it, under the influence of which currents will flow in the track structure. When the magnetic fluxes, running in the longitudinal direction, interact with the currents, inducted by them in the electrically conductive track structure MLT, traction and levitation forces are created. We note, that when the slip is equal to unity, the force of the magnetic suspension will be maximum. Under the influence of tractive force, the crew of the MLT will begin its movement. When magnetic fluxes running in the transverse direction interact with the currents, inducted by them, counterdirected lateral mechanical forces and magnetic suspension forces are created. If the transport crew is symmetrically located relative to the track structure, the lateral forces are the same, they balance each other and have no effect on the motion of the magnetic-levitation transport. If the movement of the MLT crew is displaced to the right or to the left (for example, under the influence of a strong side wind), then the equilibrium of lateral mechanical forces is violated and under the influence of the difference of these efforts the transport crew automatically returns to the former, symmetrical position. As for the magnetic suspension forces, created by the interaction of transversely running magnetic fields with currents in the track structure, they will not depend on the speed of the MLT. This is explained by the fact that the slip of the LIM inductor relative 
to the transversely running magnetic fields will always be equal to unity. The design of a linear induction motor with a longitudinal-transverse magnetic flux [16] is capable of developing large efforts of a lateral stabilization of magneticlevitation transport, by increasing the efficiency of the use of counter-current running magnetic fields. LIM with a longitudinal-transverse magnetic flux can be used in combination with an electrodynamic levitation system to accelerate the transport crew to the required speed, after which induction motors will be used in the lateral stabilization system of magnetic-levitation transport.

\section{MATHEMATICAL MODELING OF THE DISTRIBUTION OF THE MAGNETOMOTIVE FORCE LIM WITH A LONGITUDINAL-TRANSVERSE MAGNETIC FLUX}

For the electromagnetic calculation of LIM and determination of its integral characteristics, it is necessary to develop mathematical models of the machine taking into account the distribution of the magnetomotive force in the air gap and in the electrically conductive part of the secondary element (track structure MLT). Linear induction motors with longitudinal-transverse closure of magnetic flux have an open magnetic system and in their operation longitudinal and transverse end effects are manifested, which have a great influence on the traction properties of LIM. Therefore, when calculating, it is necessary to take into account the influence of end effects. In order to take into account the influence of longitudinal and transverse end effects, a linear induction motor is represented in the form of two computational models, which depict the distribution of magnetomotive forces in two mutually perpendicular directions. This approach to analyzing the properties of LIM will create a three-dimensional theory of linear electric motors with longitudinal closure of the magnetic flux. Later, an attempt was made to extend this theory to linear induction motors with a transverse magnetic flux, which made it possible to obtain good results that coincided with the experimental data. We use this approach to determine the magnetomotive force of linear induction motors with a longitudinal-transverse magnetic flux, the designs of which are intended for use on a promising highspeed magnetic-levitation and vacuum transport.

We use for analysis a number of assumptions that make it possible to obtain an analytical solution of the problem.

We assume, that the magnetic permeability of the magnetic circuit is equal to infinity; the electric conductivity of the magnetic circuit is zero; the inductor current is concentrated in an infinitely thin layer on the surface of the teeth facing the secondary element (electrically conductive path structure MLT); the current of the inductor generates in the direction of the «X» axis a 
sinusoidally traveling MMF wave; the components of the current density along the «y» axis in the inductor and the secondary element are zero.

Let us consider a linear induction motor with a longitudinal-transverse magnetic flux, intended for magnetic-levitation transport, whose magnetic system is formed by transversely laminated $\Pi$-shaped cores, between each pair of which a longitudinal magnetic circuit is located. The coils of the concentrated three-phase winding cover the teeth of longitudinally and transversely laminated cores. The design model of this linear induction motor is shown in Fig. 1. The adopted coordinate system contains the " $x$ " axis, oriented in the direction of motion, the "y»» axis, located at the center of the rail section (secondary element), and the «z» axis, directed transversely to the displacement of the inductor. In the longitudinal direction, the MMF is distributed sinusoidally, and in the transverse direction the inductor of the traction LIM with the longitudinaltransverse magnetic flux is divided into 23 zones, for which the MMF distribution is shown (Fig. 2). This representation of the MMF allows one to take into account the influence of the transverse end effect. Magnetomotive forces for each of the zones of this LIM in accordance with the calculation models are presented as:

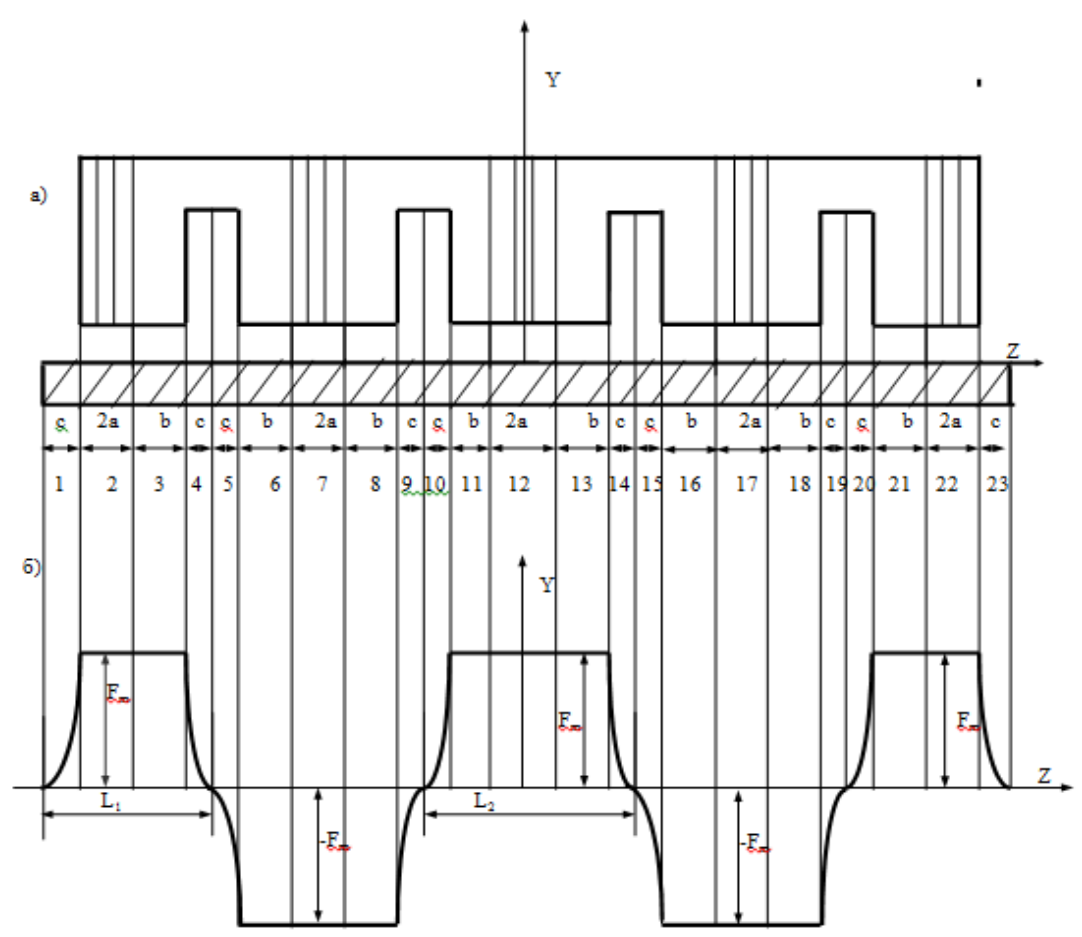

Fig 1. The design model of the LIM in the transverse direction:

a) the cross section of the LIM;

b) the distribution of the MMF in the transverse direction 


$$
\begin{aligned}
& F_{1}=F_{m}\left[1+\sin \frac{\pi(z+5 a+4 b+4 c)}{2 c}\right] e^{j\left(\omega t-\frac{\pi}{\tau} x\right)} \\
& F_{2}=F_{3}=F_{m} e^{j\left(\omega t-\frac{\pi}{\tau} x\right)} \text {; } \\
& F_{4}=F_{m}\left[1-\sin \frac{\pi(z-3 a-3 b-3 c)}{2 c}\right] e^{j\left(\omega t-\frac{\pi}{\tau} x\right)} ; \\
& F_{5}=-F_{m}\left[1+\sin \frac{\pi(z+3 a+3 b+2 c)}{2 c}\right] e^{j\left(\omega t-\frac{\pi}{\tau} x\right)} \text {; } \\
& F_{6}=F_{7}=F_{8}=-F_{m} e^{j\left(\omega t-\frac{\pi}{\tau} x\right)} \text {; } \\
& F_{9}=-F_{m}\left[1-\sin \frac{\pi(z-a-b-c)}{2 c}\right] e^{j\left(\omega t-\frac{\pi}{\tau} x\right)} ; \\
& F_{10}=F_{m}\left[1+\sin \frac{\pi(z+a+b)}{2 c}\right] e^{j\left(\omega t-\frac{\pi}{\tau} x\right)} \text {; } \\
& F_{11}=F_{12}=F_{13}=F_{m} e^{j\left(\omega t-\frac{\pi}{\tau} x\right)} \text {; } \\
& F_{14}=F_{m}\left[1-\sin \frac{\pi(z-a-b)}{2 c}\right] e^{j\left(\omega t-\frac{\pi}{\tau} x\right)} \text {; } \\
& F_{15}=-F_{m}\left[1+\sin \frac{\pi(z+a+b+c)}{2 c}\right] e^{j\left(\omega t-\frac{\pi}{\tau} x\right)} \text {; } \\
& F_{16}=F_{17}=F_{18}=-F_{m} e^{j\left(\omega t-\frac{\pi}{\tau} x\right)} \text {; } \\
& F_{19}=-F_{m}\left[1-\sin \frac{\pi(z-3 a-3 b-2 c)}{2 c}\right] e^{j\left(\omega t-\frac{\pi}{\tau} x\right)} \text {; } \\
& F_{20}=F_{m}\left[1+\sin \frac{\pi(z+3 a+3 b+3 c)}{2 c}\right] e^{j\left(\omega t-\frac{\pi}{\tau} x\right)} ; \\
& F_{21}=F_{22}=F_{m} e^{j\left(\omega t-\frac{\pi}{\tau} x\right)} \text {; } \\
& F_{23}=F_{m}\left[1-\sin \frac{\pi(z-5 a-4 b-4 c)}{2 c}\right] e^{j\left(\omega t-\frac{\pi}{\tau} x\right)} .
\end{aligned}
$$

Where $F_{m}=\frac{2 \sqrt{2}}{\pi} q m w_{c} I_{K} k_{o \delta 1}$

LIM with a longitudinal-transverse magnetic flux, the cross-section of which is shown in Fig. 1, can be represented as the sum of five linear motors, operating according to: three median, whose MMF change in the transverse 
direction with a period of $T_{2}=2 L_{2}$, and two extreme, whose magnetomotive force has a period of $T_{1}=2 L_{1}$ along the «z» axis.

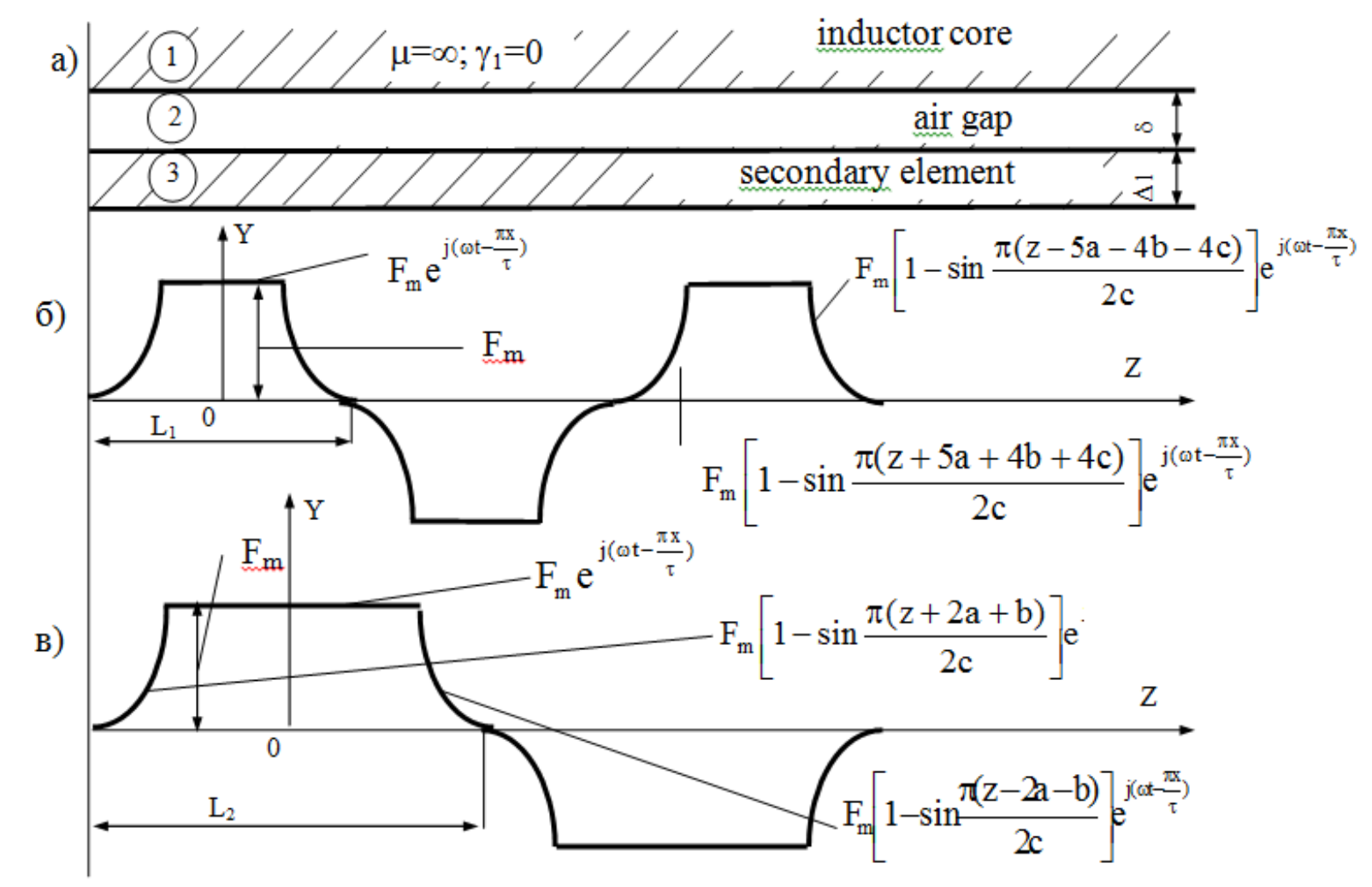

Fig 2. Design model and MMF of linear motor in the transverse direction:

a) the design model; b) distribution of MMF of median LIM; c) distribution of MMF of extreme LIM

In this case, the calculation can be performed separately for LIM 1, and the calculation results are doubled, and for LIM 2 (the results of the calculation are tripled). Summing the results of the calculation of LIM 1 and LIM 2, we obtain integral values of the parameters and characteristics of the LIM with a longitudinal-transverse magnetic flux.

A more detailed design model of the LIM (Fig. 2) denotes three zones:

1 - magnetic inductor system;

2 - air gap;

3 - conductive secondary element (track structure MLT).

When analyzing design models, we use the assumptions made earlier.

Design models and assumptions made earlier (Fig. 1 and Fig. 2) make it possible to represent the MMF of the extreme LIM 1 in the form of a periodic function with the period $T_{x}=1$ along the $" x$ » axis and with the $T_{z}=2 L_{1}$ period along the «z» axis in the form: 


$$
F_{1}(x, z, t)=\left\{\begin{array}{l}
F_{m} e^{j\left(\omega t-\frac{\pi}{\tau} x\right)} ; \\
\text { on condition }-\mathrm{p} \tau \leq x \leq p \tau ;-(5 a+4 b+4 c) \leq z \leq-(3 a+3 b+3 c) ; \\
F_{m}\left[1-\sin \frac{\pi(z-5 a-4 b-4 c)}{2 c}\right] e^{j\left(\omega t-\frac{\pi}{\tau} x\right)} ; \\
\text { on condition }-\mathrm{p} \tau \leq x \leq p \tau ;-(3 a+3 b+3 c) \leq z \leq-(3 a+3 b+2 c) ; \\
F_{m}\left[1+\sin \frac{\pi(z+5 a+4 b+4 c)}{2 c}\right] e^{j\left(\omega t-\frac{\pi}{\tau} x\right)} ; \\
\text { on condition }-\mathrm{p} \tau \leq x \leq p \tau ;-(5 a+4 b+4 c) \leq z \leq-(5 a+4 b+3 c) ;
\end{array}\right.
$$

where $\mathrm{F}_{\mathrm{m}}=\frac{2 \sqrt{2}}{\pi} \mathrm{qmw}_{\mathrm{c}} \mathrm{I}_{\mathrm{c}} \mathrm{K}_{\mathrm{o \sigma} 1}$;

Magnetomotive force of the median LIM-2 can be represented as periodic functions with a period of $\mathrm{T}_{\mathrm{x}}=1$ along the $\left\langle\mathrm{X}\right.$ » axis and with a period $\mathrm{T}_{\mathrm{Z}}=2 \mathrm{~L}_{2}$ along the «Z» axis, given as follows:

$$
F_{2}(x, z, t)=\left\{\begin{array}{l}
F_{m} e^{j\left(\omega t-\frac{\pi}{\tau} x\right)} ; \\
\text { on condition }-\mathrm{p} \tau \leq x \leq p \tau ;-(2 a+b+c) \leq z \leq(2 a+b+c) ; \\
F_{m}\left[1-\sin \frac{\pi(z-2 a-b)}{2 c}\right] e^{j\left(\omega t-\frac{\pi}{\tau} x\right)} ; \\
\text { on condition }-\mathrm{p} \tau \leq x \leq p \tau ;-(2 a+b) \leq z \leq(2 a+b+c) ; \\
F_{m}\left[1+\sin \frac{\pi(z+2 a+b)}{2 c}\right] e^{j\left(\omega t-\frac{\pi}{\tau} x\right)} ; \\
\text { on condition }-\mathrm{p} \tau \leq x \leq p \tau ;-(2 a+b+c) \leq z-(2 a+b) ;
\end{array}\right.
$$

Having performed a number of transformations, we represent the MMF of the «extreme» and middle LIM in the form of double Fourier series

For the extreme LIM the magnetomotive force is obtained as:

$$
\begin{gathered}
F_{1}(x, z, t)=\frac{8 \tau F_{m}}{\pi^{2} l} \sum_{n} \sum_{v} n_{11}\left(\pi n \frac{z}{L_{1}}\right) v_{k} e^{j\left(\omega t+2 \pi v \frac{x}{l}\right)} \\
\mathrm{n}_{\text {л1 }}=\frac{1}{\mathrm{n}\left[1-\left(2 \mathrm{n} \frac{\mathrm{c}}{1}\right)^{2}\right]}\left[\sin \frac{\pi \mathrm{n}\left(\mathrm{a}+\frac{\mathrm{b}}{2}+\mathrm{c}\right)}{\mathrm{L}_{1}}-2 \mathrm{n} \frac{\mathrm{c}}{\mathrm{L}_{1}} \cos \left(\pi \mathrm{n} \frac{\mathrm{a}+\frac{\mathrm{b}}{2}}{\mathrm{~L}_{1}}\right)\right]
\end{gathered}
$$


where $\mathrm{n}-$ an integer, positive, odd number - order harmonic component of the MMF in the «z» axis direction, with the period of the first harmonic being $2 \mathrm{~L}_{1}=2(2 \mathrm{a}+\mathrm{b}+\mathrm{c})$;

$v$ - harmonic order of the MMF along the « $\mathrm{X} »$ axis;

$\mathrm{n}_{\text {Л1 }}$ - a coefficient, that takes into account the MMF distribution in the zone of the frontal parts of the LIM 1 winding;

$v_{K}-a$ coefficient, that takes into account the number of poles.

The magnetomotive force of the median LIM 2 is defined as follows:

$$
\begin{gathered}
F_{2}(x, z, t)=\frac{8 \tau F_{m}}{\pi^{2} l} \sum_{n} \sum_{v} n_{л 2}\left(\pi n \frac{z}{L_{2}}\right) v_{k} e^{j\left(\omega t+2 \pi v \frac{x}{l}\right)}, \\
\mathrm{n}_{\text {л2 }}=\frac{1}{\mathrm{n}\left[1-\left(2 \mathrm{n} \frac{\mathrm{c}}{\mathrm{l}}\right)^{2}\right]}\left[\sin \frac{\pi \mathrm{n}(\mathrm{a}+\mathrm{b}+\mathrm{c})}{\mathrm{L}_{2}}-2 \mathrm{n} \frac{\mathrm{c}}{\mathrm{L}_{2}} \cos \left(\pi \mathrm{n} \frac{\mathrm{a}+\mathrm{b}}{\mathrm{L}_{2}}\right)\right],
\end{gathered}
$$

where $\mathrm{L}_{2}=2(2 \mathrm{a}+2 \mathrm{~b}+2 \mathrm{c})$.

\section{CONCLUSIONS}

1. The proposed method for modeling the distribution of the magnetomotive force LIM with a longitudinal-transverse magnetic flux makes it possible to reduce the real models of linear induction motors with a longitudinaltransverse magnetic flux with the complex structure of the magnetic inductor systems to the calculated mathematical ones. This can serve as a basis for creating a methodology for calculating the parameters and characteristics of traction LIM with a longitudinal-transverse magnetic flux, intended for use in high-speed magnetic-levitation and vacuum transport.

2. Linear induction motors with a longitudinal-transverse magnetic flux in high-speed MLT systems are capable, along with traction and levitation efforts, to realize automatic lateral self-stabilization of the transport crew relative to the track structure and are multi-functional devices.

3. Linear induction motors with a longitudinal-transverse magnetic flux in combination with an electrodynamic system of magnetic levitation are promising for magnetic-levitation transport.

\section{БИБЛИОГРАФИЧЕСКИЙ СПИСОК / References}

1. Антонов Ю.Ф., Зайцев А.А. Магнитолевитационная транспортная технология. - Москва: Издательство физико-математической литературы, 2014. - 476 с. [Antonov YuF, Zaitsev AA. Magnitolevitatsionnaya transportnaya tekhnologiya. Moscow: Izdatel'stvo fiziko-matematicheskoy literatury; 2014. 476 p. (In Russ.)].

2. Зайцев А.А., Талашкин Г.Н., Соколова Я.В. Транспорт на магнитном подвесе. СПб: Издательство Петербургского государственного университета путей сообщения, 2010. - 160 с. [Zaitsev AA, Talashin GN, Sokolova YaV. Transport na 
magnitnom podvese. St. Petersburg: Izdatel'stvo Peterburgskogo universiteta pytei soobkheniya; 2010. 160 p. (In Russ.)].

3. Антонов Ю.Ф., Зайцев А.А. Магнитолевитационный транспорт: научные проблемы и технические решения. - Москва: Издательство физикоматематической литературы, 2015. - 612 с. [Antonov YuF, Zaitsev AA. Magnitolevitatsionnyy transport: nauchnyye problem i tekhnicheskiye resheniya. Moscow: Izdatel'stvo fiziko-matematicheskoy literatury; 2015. 612 p. (In Russ.)].

4. Зайцев А.А., Морозова Е.Н., Талашкин Г.Н. и др. Магнитолевитационный транспорт в единой транспортной системе страны. - Санкт-Петербург: ООО «Типография «НП-ПРИНТ», 2015. - 140 с. [Zaitsev AA, Morozova EN, Talashin GN., et al. Magnitolevitatsionnyy transport $\mathrm{v}$ edinoi transportnoi sisteme strany. St. Petersburg: OOO 'Tipografia 'NP-PRINT'; 2015. 140 p. (In Russ.)].

5. Зайцев А.А. О современной стадии развития магнитолевитационного транспорта // Железнодорожный транспорт. - 2016. - № 12. - С. 62-65. [Zaitsev AA. O sovremennoy stadii razvitiya magnitolevitatsionnogo transporta. Zheleznodorozhnyy transport. 2016;(12):62-65. (In Russ)].

6. Зайцев A.A. Магнитолевитационные системы и технологии // Железнодорожный транспорт. - 2014. - № 5. - C. 69-73. [Zaitsev AA. Magnitolevitatsionnye sistemy i technologii. Zheleznodorozhnyy transport. 2014;(5):69-73. (In Russ.)].

7. Антонов Ю.Ф., Зайцев А.А., Морозова Е.И. Исследование магнитодинамической левитации и электродинамического торможения грузовой транспортной платформы // Известия ПГУПС. - 2014. - Т. 4. - № 41. - C. 5-15. [Antonov YuF, Zaitsev AA, Morozova EI. Issledovanie magnitodinamicheskoi levitatsii i electrodinamichescogo tormozenia gruzovoi transportnoi platformy. Izvestia PGUPS. 2014;4(41):5-15. (In Russ.)].

8. Авторское свидетельство СССР на изобретение № 696579/05.11.79. Бюл. № 41 . Попов А.Д., Соломин В.А., Хантимиров С.С. и др. Линейный асинхронный двигатель. Режим доступа: http://patents.su/2-696579-linejjnyjj-asinkhronnyjjdvigatel.html. [Author’s certificate the USSR № 696579/05.11.79. Byul. № 41. Popov AD, Solomin VA, Chantimirov SS et al. Lineinyi asinhronnyi dvigatel. Available from: http://patents.su/2-696579-linejjnyjj-asinkhronnyjj-dvigatel.html. (In Russ.)].

9. Popov AD, Solomin VA, Khantimirov SS, et al, inventor. Linear inducton motor. United States patent US 4216397. 1980 Aug 5. Available from: https://patents.google.com/patent/US4216397A/en.

10. Popov AD, Solomin VA, Chantimirov SS und. and, inventor. Linearer Asynchron motor. Bundesrepublik Deuschland patent 2851038. 1983 Aug 11. Available from: https://patents.google.com/patent/DE2851038A1/en?oq=Pat.+2851038+Bundesrepublik + Deuschland.

11. Popov AD, Solomin VA, Khantimirov SS, inventor. Moteur electrigue asynchrone a movement lineaire. France patent 7836932. 1981 Oct. 23. Available from: https://patents.google.com/patent/US7836932B2/en?oq=Pat.+7836932+France.

12. Авторское свидетельство СССР на изобретение № 868942/30.09.81. Бюл. №. 36. Попов А.Д., Соломин В.А., Хантимиров С.С., Шириков А.А. Линейный асинхронный двигатель. Режим доступа: http://patents.su/3-868942-linejjnyjjasinkhronnyjj-dvigatel.html. [Author's certificate the USSR № 868942/30.09.81. Byul. № 36. Popov AD, Solomin VA, Chantimirov SS, Shirikov AA. Lineinyi asinhronnyi dvigatel. Available from: http://patents.su/3-868942-linejjnyjj-asinkhronnyjjdvigatel.html. (In Russ)]. 
13. Popov AD, Solomin VA, Khantimirov SS, et al, inventor. Linear inducton motor. United States patent US 4271367. 1981 Jun. 2. Available from: https://patents.google.com/patent/US4271367A/en?oq=Pat.+4271367+United+States.

14. Popov AD, Solomin VA, Chantimirov SS, et al, inventor. Linearer Asynchron motor. Bundesrepublik Deuschland patent 3012917. 1984 March 8. Available from: https://patents.google.com/patent/DE3012917A1/en?oq=Pat.+3012917+Bundesrepublik + Deuschland.

15. Popov AD, Solomin VA, Khantimirov SS, et al, inventor. Moteur electrigue asynchrone a movement lineaire. France patent 8008928. 1983 Feb. 25. Available from: https://patents.google.com/patent/US8008928B2/en?oq=Pat.+8008928+France.

16. Патент РФ на изобретение № 2268543/20.01.06. Бюл. № 2. Соломин А.В. Линейный асинхронный двигатель. Режим доступа: http://bd.patent.su/22680002268999/pat/servl/servletb65f.html. [Pat. RUS № 2268543/20.01.06. Byul. №.2. Solomin AV. Lineinyi asinhronnyi dvigatel. Available from: http://bd.patent.su/2268000-2268999/pat/servl/servletb65f.html. (In Russ.)].

\section{Information about the authors:}

Vladimir A. Solomin, Doctor of Technological sciences, Professor; address: 2, Rostovskogo Strelkovogo Polka Narodnogo Opolcheniya sq., Rostov-on-Don, 344038, Russia; eLibrary SPIN: 6785-9031; ORCID: 0000-0002-0638-1436;

E-mail: ema@rgups.ru.

Andrei V. Solomin, Candidate of Technological sciences, Associate Professor; eLibrary SPIN: 7805-9636; ORCID: 0000-0002-2549-4663;

E-mail:vag@kaf.rgups.ru.

Victor V. Koledov, Doctor of physico-mathematical Sciences, Professor Russian Academy of Sciences; eLibrary SPIN: 9291-1989; ORCID: 0000-0002-2439-6391;

E-mail: victor_koledov@mail.ru.

Nadezda A. Trubitsina, Candidate of Technological sciences, Associate Professor; eLibrary SPIN: 4192-0487; ORCID: 0000-0001-6640-8306;

E-mail: ema@rgups.ru.

\section{Сведения об авторах:}

Соломин Владимир Александрович, доктор технических наук, профессор; 344038, Ростов-на-Дону, пл. Ростовского Стрелкового Полка Народного Ополчения, 2; eLibrary SPIN:6785-9031; ORCID: 0000-0002-0638-1436;

E-mail: ema@rgups.ru

Соломин Андрей Владимирович, кандидат технических наук, доцент; eLibrary SPIN:7805-9636; ORCID: 0000-0002-2549-4663;

E-mail: vag@kaf.rgups.ru

Коледов Виктор Викторович, доктор физико-математических наук, профессор РАН; eLibrary SPIN: 9291-1989; ORCID: 0000-0002-2439-6391;

E-mail: victor_koledov@mail.ru 
Трубицина Надежда Анатольевна, кандидат технических наук, доцент; телефон: $+7(863) 2726212$;

eLibrary SPIN: 4192-0487; ORCID: 0000-0001-6640-8306;

E-mail: ema@rgups.ru

\section{To cite this article:}

Solomin VA, Solomin AV, Koledov VV, Trubitsina NA. Multifunctional Linear Induction Motor with Longitudinal-Transverce Magnetic Flux for Magnetic-Levitational Transport. Transportation Systems and Technology. 2018;4(2):167-179. doi: 10.17816/transsyst201842167-179

\section{Цитировать:}

Соломин В.А., Соломин А.В., Коледов В.В., Трубицина Н.А. Многофункциональный линейный асинхронный двигатель с продольно-поперечным магнитным потоком для магнитолевитационного транспорта // Транспортные системы и технологии. - 2018. - T. 4. - № 2. - C.167-179. doi: 10.17816/transsyst201842167-179 